\title{
Expression levels of heat shock proteins through western blot and real-time polymerase chain reaction in maize
}

\author{
Mohamed Abdel-Salam Rashed ${ }^{1}$, Mahmoud Hussien Abou-Deif ${ }^{2, *}$, Kamal Mohamed \\ Khalil $^{2}$ and Fatma El-Sayed Mahmoud ${ }^{2}$ \\ ${ }^{1}$ Genetic Dept., Agric. Fac., Ain Shams Univ., Cairo, Egypt ${ }^{2}$ Genetic and Cytology Dept., National Research Centre, 12311 Dokki, Giza, \\ Egypt.
}

Received: March 10, 2020; Revised: September 29, 2020; Accepted: Oct 26, 2020

\begin{abstract}
High temperature stress (HTS) is one of the most detrimental abiotic stresses which adversely affect productivity of maize (Zea mays L.). Plants respond to HTS by regulating expression of many genes including heat shock proteins (HSPs). We carried out expression analysis of six HSP genes by western blot (WB) and real-time polymerase chain reaction (RT-PCR) in four contrasting Egyptian maize lines, i.e. K1, K7, G342 (heat tolerant) and Rg59 (heat susceptible), subjected to HTS at seedling stage. The six-maize specific HSP genes (ZmHSP70, ZmHSP22, ZmHSP17.9, ZmHSP17.6, ZmHSP16.9 and transcription factor ZIP60) exhibited distinctive expression patterns in response to heat stress (HS). Higher upregulation of ZmHSP70, ZmHSP22, ZmHSP17.9 and ZmHSP17.6 were found throughout the stress exposure at $45^{\circ} \mathrm{C}$ for 2 and 4 hours in the heat tolerant lines as compared to the control $\left(25^{\circ} \mathrm{C}\right)$ and susceptible line. Meanwhile, the susceptible line showed expression of many HSP genes in the control, but these genes were down-regulated by HS. The line K1 showed expression level for ZmHSP70, ZmHSP17.9, ZmHSP17.6 and ZmHSP16.9 genes more than the other lines indicating its highly tolerance against HTS. Higher upregulation of these six genes in the heat tolerant lines indicated their possible role in protecting plant from adverse effects of HS.
\end{abstract}

Keywords: Maize, Heat shock proteins, Heat tolerance, Western blot, RT- PCR, Genes.

\section{Introduction}

Plant productivity is related to the ability of plants to adapt to environmental stress (Sachs and Ho, 1986). Many stress proteins have been proposed to function during stress in the binding of denatured proteins, thus preventing their degradation, and in the refolding of these proteins into their native structure (Schröder et al., 1993; Hendrick and Hartl, 1993). WB is a sensitive immunological method to investigate protein abundance, cellular localization, protein-protein interactions, detection of antigens in crude mixtures of proteins and clinical applications in autoimmune diseases. Specific antibodies are a reliable tool to examine protein expression patterns and to determine the protein localizations within cells (Burnette, 1981; Okegawa et al., 2016; Bass et al., 2017).

Lenne and Douce (1994) reported that when pea (Pisum sativum) plants are shifted from $25^{\circ} \mathrm{C}$ up to $40^{\circ} \mathrm{C}$ for $3 \mathrm{~h}$, $22-\mathrm{kD}$ protein was produced in mitochondria. HSP22 was used as antigen to prepare antiserum, which the expression of HSP22 was studied using immunodetection methods. Examination of mitochondria matrix extracts by polyacrylamide gel electrophoresis (PAGE) and immune blotting with anti-HSP22 serum revealed HSP complex contains HSP22. Lenne et al. (1995) purified HSP22 and developed a polyclonal antibody. Use of antiserum allowed them to show that the HS response is a rapid process since HSP22 can be detected in total protein extracts as early as $30 \mathrm{~min}$ after treatment at $40^{\circ} \mathrm{C}$ of pea (Pisum sativum). Lund et al. (1998) identified mitochondrial HSP70 and cpn60 in maize inbred "B73" using two dimensional-PAGE (2D-PAGE) and immuneblots. During $\mathrm{HS}$ at $42^{\circ} \mathrm{C}$ for $4 \mathrm{~h}$, the level of HSP22 increased dramatically. Monoclonal antibodies were developed to maize HSP70, cpn60, and HSP22. Maximal HSP22 expression occurred in etiolated seedling mitochondria after $5 \mathrm{~h}$ of a $+13^{\circ} \mathrm{C}$ HS. Li et al. (2011) carried out WB to detect the expression of target proteins in a set of 10 rice samples. The results indicated that HSP was the most constantly expressed among all rice proteins tested throughout all developmental stages. They found that the reference proteins and the corresponding antibodies can be used in qualitative and quantitative analysis of rice proteins.

RT-PCR has become one of the most widely used methods of gene quantitation because it has a large dynamic range, can be highly sequence-specific and has little post-amplification processing. In addition, many diagnostic applications have been developed, including microbial quantification, identification of transgenes in genetically modified foods and applications for forensic use (Wong and Medrano, 2005; Berg et al., 2007). The fluorescence-based quantitative RT-PCR (qRT-PCR) is an accurate tool to analyze gene expression, which mRNA normalization requires internal control genes are stably

\footnotetext{
*Corresponding author e-mail: aboudeif@yahoo.com.
} 
expressed should be used. Reference genes, which serve as endogenous controls to ensure that the results are accurate and reproducible, are vital for data normalization (Lilly et al., 2011; Zhang et al., 2013; Lin et al., 2014).

$\mathrm{Li}$ et al. (2015) found that, using qRT-PCR, the expression level of $\mathrm{ZmHsf06}$ was raised by heat stress to different extents in three Arabidopsis transgenic lines. Phenotypic observation showed over-expressing of ZmHsfO6 in Arabidopsis plants, which enhanced basal and acquired thermo-tolerance under HS conditions. Zhao et

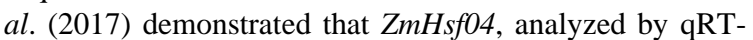
PCR, was expressed in multiple tissues of maize. Expression level of $\mathrm{ZmHsf04}$ was up-regulated significantly by $\mathrm{HS}$ at $42^{\circ} \mathrm{C}$, especially in pollens with the value of 16 times of the control. Song et al. (2016) isolated HSP70 gene from maize designated as ZmERD2 (Early Responsive to Dehydration 2). Expression of ZmERD2 was analyzed by qRT-PCR in maize found to be induced by $\mathrm{HS}$ and dehydration treatments. The expression was induced at $42^{\circ} \mathrm{C}$ and reached 40 -fold above the control level after one hour of HS. Kumar et al. (2019) characterized five HSP genes and their expression analysis in two contrasting maize lines, i.e. LM17 (heat tolerant) and HKI1015WG8 (heat susceptible) subjected to HTS. The five-maize specific HSP genes, viz., ZmHsp26, ZmHsp60, ZmHsp70, ZmHsp82 and ZmHsp101 exhibited different expression pattern in response to HS. They found higher upregulation of ZmHsp70 and ZmHsp101 throughout the stress exposure in the heat tolerant line as compared to the susceptible line.

The objectives of this study are quantification of expression levels of HSP genes in four Egyptian maize lines by WB and RT-PCR analyses and identification of specific genes playing essential role in HS tolerance for developing stress resistant genotypes.

\section{Materials and methods}

\subsection{Plant materials}

Four Egyptian inbred lines of maize (Zea mays L.) were used in this study. Two lines K1 and K7 were developed by the plant breeding group, National Research Centre, Giza, Egypt. The other two lines G342 and Rg59 were kindly supplied by the Agriculture Research Center, Giza, Egypt. The four lines were previously studied to identify HSPs under $\mathrm{HS}$ at $45^{\circ} \mathrm{C}$ as protein markers for detecting the thermo-tolerance lines. The results indicated that the three lines K1, K7 and G342 are tolerant and the line Rg59 is susceptible (Mahmoud et al., 2018).

\subsection{Western blot analysis}

The proteins were separated on one-dimensional gel and transferred to nitrocellulose membranes according to Towbin et al. (1979). The membrane was incubated with PBS buffer (1.6 mM $\quad \mathrm{PO}_{4} \mathrm{H}_{2} \mathrm{Na}_{2} \mathrm{H}_{2} \mathrm{O}, \quad 8.4 \mathrm{mM}$ $\mathrm{PO}_{4} \mathrm{HNa}_{2} .2 \mathrm{H}_{2} \mathrm{O}, 150 \mathrm{mM} \mathrm{NaCl}, \mathrm{pH} 7.4$.), $0.1 \%$ Tween 20 and $3 \%$ skimmed milk buffer for one hour at RT on shaker. PBS buffer was used to wash the membrane three times each time for $5 \mathrm{~min}$, then the first antibody (Bibhsp17.6/ hsp22 with dilution 1:1000 and hsp17.9/ hsp70 with dilution 1:4000) was added in PBS buffer with $0.1 \%$ Tween 20 and 3\% skimmed milk. The membrane was incubated for $2 \mathrm{~h}$ at RT, then washed three times with PBS buffer with $0.1 \%$ Tween 20 , each time for $5 \mathrm{~min}$. The second antibody (anti-Rabbit) was added with dilution 1:1000 in PBS buffer with $0.1 \%$ Tween 20 and 3\% skimmed milk; then incubated for $2 \mathrm{~h}$ at RT and washed three times with PBS buffer. The proteins on membrane were detected after maintaining for the needed time, then exposed to autoradiography using LAS 4000 instrument. Immunoreactive bands were visualized with a highly sensitive chemiluminescent substrate for peroxidase detection (GE Healthcare Europe GmbH, Freiburg, Germany). The Actin gene was used as reference gene to normalize the expression values.

\subsection{Real Time PCR analysis}

The expression levels of three HS genes markers (ZIP60 transcription factor, hsp22 and hsp16.9) were detected by RT-PCR for the four maize lines K1, K7, G342 and Rg59. The primers listed in Table (1) were designed using Primer Express Software (Applied Biosystems, Foster City, CA, USA). Total RNA preparation, first-strand cDNA synthesis and RT-PCR were performed as described by Cui et al. (2012). DNaseItreated total RNA was subjected to reverse transcription using QuantiTect Reverse Transcription kit (Qiagen, Germany), cDNA samples from three independent replicates were analyzed by FluidiGM system (San Francisco, CA, USA). Master mix tubes (Invitrogen, USA) were used in the reactions, each tube containing: dNTPs, $\mathrm{MgCl}_{2}$, RT-PCR buffer and Taq DNA polymerase. The concentration of the primers was $10 \mu \mathrm{M} / \mu \mathrm{l}$ and cDNA concentration was $15 \mathrm{ng} / \mu \mathrm{l}$. After the reactions were mixed, vortexed for 30 second then centrifuged at 1600 rpm for one min. The reactions of RT-PCR were applied in Roche Light Cycler 480 instrument using SYBR Green I dye. Three biological replicates were performed. The expression level in leaf tissue from unstressed control plants was selected as calibrator.

Table 1. List of the specific primers for qRT-PCR and their nucleotide sequences.

\begin{tabular}{lll}
\hline No. & Gene name & Sequence (primer direction 5’3’) \\
\hline 1 & HSP22 & F- GAGGGCGAGAAGGAGGATAG \\
& & R- CTCGACGTTGACTTGGAACA \\
2 & HSP16.9 & F- GAACGGATAGTAGCGTCCCA \\
& & R- CAATGCAGGAATACCACCCT \\
3 & ZIP60 & F- AGGATAGGCCTCTTGGTGCT \\
& & R- TTCCATGGAGGATGAGTTCC \\
\hline
\end{tabular}

HSP22: Heat Shock Protein 22, HSP16.9: Heat Shock Protein 16.9, ZIP60: Zipper (ZIP) transcription factor 60, F: Forward, R: Reverse.

\section{Results}

Resistance of the four maize inbred lines to high temperature correlates with the expression levels of HSP markers was detected through two experiments, WB and RT-PCR.

\subsection{WB analysis}

A comparative analysis of induction levels of four protein markers (HSP70, HSP22, HSP17.9 and HSP17.6) by WB was carried out using four various antibodies. 


\subsubsection{Detection of HSP70 in response to HS by BiP antibody}

BiP polyclonal antibody was performed in rabbit against C-terminal domain of tobacco HSP70. The reagents of $\mathrm{BiP}$ antibody with the extracted proteins from seedling leaves of the inbred lines K1, K7, G342 and Rg59 are shown in Figure (1). The expression bands of reactions were visualized by PAGE analysis. The three lines K1, K7 and G342 showed bands in the control increased in intensity after exposing to $\mathrm{HS}$ treatment at $45^{\circ} \mathrm{C}$ for 2 and $4 \mathrm{~h}$. An intensive band was present in the control of the line Rg59 and decreased with the time of exposing to HS treatment.

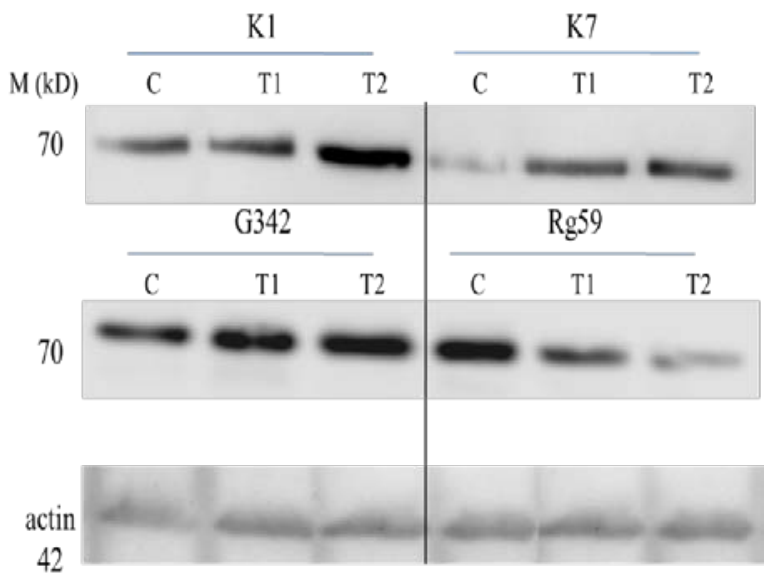

Figure 1. WB of the seedling proteins $(10 \mu \mathrm{g} / \mathrm{lane})$ extracted from control and heat- treated plants of indicated inbred lines probed with $\mathrm{BiP}$ antibody (dilution 1:1000). $\mathrm{C}\left(\right.$ control) $=25^{\circ} \mathrm{C}, \mathrm{T} 1=$ treatment at $45^{\circ} \mathrm{C}$ for $2 \mathrm{~h}$ and $\mathrm{T} 2=$ treatment at $45^{\circ} \mathrm{C}$ for $4 \mathrm{~h}$. M: molecular weight $(\mathrm{kD})$. Actin antibody is used as a total protein loading control.

\subsubsection{Detection of HSP22 in response to HS by HSP22 antibody}

HSP22 polyclonal antibody against tobacco mtHSP23 was used to detect HSP22 in maize inbred lines in response to HS (Figure 2). The reaction of HSP22 antibody with the seedling leaves proteins extracted from the lines K1, K7 and G342 did not detect any expression band in the control, while the expression level of upregulation varied in different lines after exposing to HS treatment at $45^{\circ} \mathrm{C}$ for 2 and $4 \mathrm{~h}$. The line $\mathrm{K} 1$ showed a faint band at $45^{\circ} \mathrm{C}$ for $2 \mathrm{~h}$ and clear band after exposing to $45^{\circ} \mathrm{C}$ for $4 \mathrm{~h}$, while the contrary was found in the line $\mathrm{K} 7$. The expression increased rapidly in the line G342 after 2 and $4 \mathrm{~h}$ of heat exposure. In contrast in the line Rg59, the expression level was high in the control but disappeared after treatment at $45^{\circ} \mathrm{C}$ for $2 \mathrm{~h}$ while appeared very faint after exposing to $45^{\circ} \mathrm{C}$ for $4 \mathrm{~h}$.

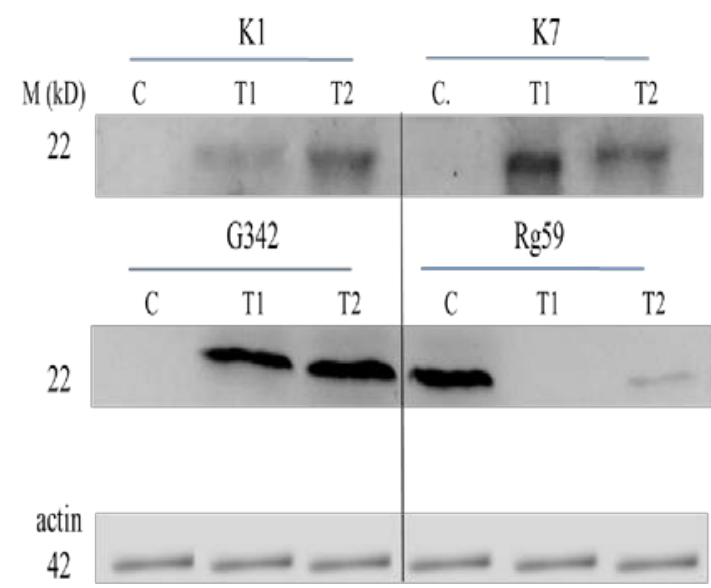

Figure 2. WB of the seedling proteins ( $25 \mu \mathrm{g} / \mathrm{lane})$ extracted from the control and heat-treated plants of indicated inbred lines probed with HSP22 Antibody (dilution 1:1000). C (control) $=25^{\circ} \mathrm{C}, \mathrm{T} 1=$ treatment at $45^{\circ} \mathrm{C}$ for $2 \mathrm{~h}$ and $\mathrm{T} 2=$ treatment at $45^{\circ} \mathrm{C}$ for $4 \mathrm{~h}$. M: molecular weight $(\mathrm{kD})$. Actin antibody is used as a total protein loading control.

\subsubsection{Detection of HSP17.9 in response to HS by HSP17.9 Antibody}

HSP17.9 polyclonal antibody against sunflower recombinant proteins made in rabbit was utilized in detection of HSP17.9 in maize inbred lines in response to HS (Figure 3). The reaction of HSP17.9 antibody against inbred line $\mathrm{K} 1$ proteins did not manifest any expression band in the control, while an expression band appeared after exposing to $\mathrm{HS}$ of $45^{\circ} \mathrm{C}$ for $2 \mathrm{~h}$ and was more visibility after $4 \mathrm{~h}$. The expression level was very faint in the inbred K7 after exposing to HS, while appeared clearly in the line G342 after $4 \mathrm{~h}$ of exposure. The expression was very faint in the control of the line Rg59 while disappeared after heat treatment.

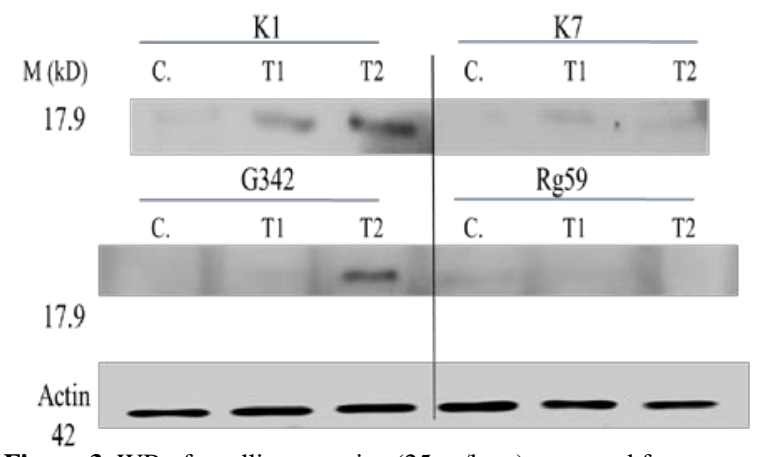

Figure 3. WB of seedling proteins ( $25 \mu \mathrm{g} / \mathrm{lane})$ extracted from control and heat-treated plants of indicated inbred lines probed with HSP17.9 antibody (dilution 1:4000). C (control) $=25^{\circ} \mathrm{C}, \mathrm{T} 1$ $=$ treatment at $45^{\circ} \mathrm{C}$ for $2 \mathrm{~h}$ and $\mathrm{T} 2=$ treatment at $45^{\circ} \mathrm{C}$ for $4 \mathrm{~h} . \mathrm{M}$ molecular weight $(\mathrm{kD})$. Actin antibody is used as a total protein loading control.

\subsubsection{Detection of HSP17.6 in response to HS by HSP17.6 antibody}

HSP17.6 polyclonal antibody against sunflower recombinant protein made in rabbit was utilized in detection of HSP17.6 in maize lines in response to HS (Figure 4). The reaction of HSP17.6 antibody with the proteins of inbred lines K1 and G342 did not give any expression in the control while intensive expression appeared after exposing to heat treatment at $45^{\circ} \mathrm{C}$ for $2 \mathrm{~h}$ and was more intensity after $4 \mathrm{~h}$. Significant expression 
was visualized in the lines K7 and Rg59 which increased gradually after exposing to heat treatment.

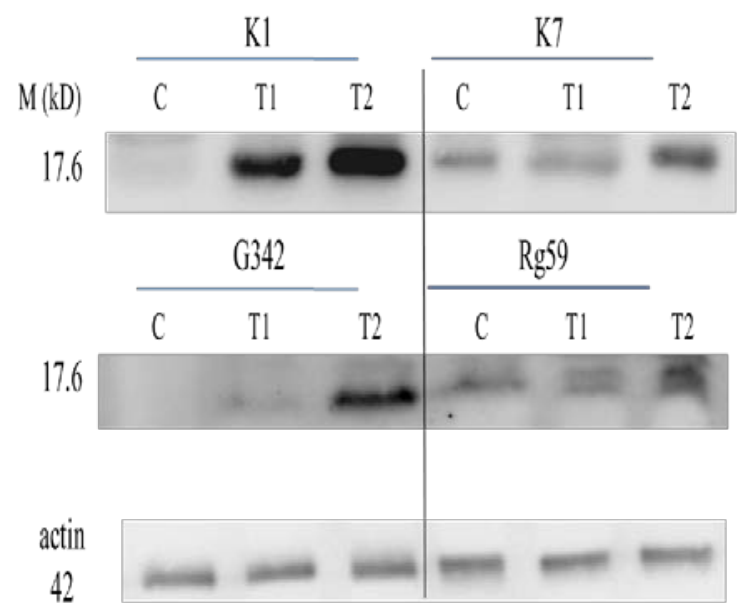

Figure 4. WB of the seedling proteins (25 $\mu \mathrm{g} / \mathrm{lane})$ extracted from the control and heat-treated plants of indicated inbred lines probed with HSP17.6 antibody (dilution 1:1000). C (control) $=25^{\circ} \mathrm{C}, \mathrm{T} 1$ $=$ treatment at $45^{\circ} \mathrm{C}$ for $2 \mathrm{~h}$ and $\mathrm{T} 2=$ treatment at $45^{\circ} \mathrm{C}$ for $4 \mathrm{~h}$. $\mathrm{M}$ : molecular weight $(\mathrm{kD})$. Actin antibody is used as a total protein loading control.

\subsection{RT-PCR analysis}

The expression levels of the three heat-induced gene markers ZmHSP22, ZmHSP16.9 and ZIP60 were estimated by RT-PCR. The quantitation of plant gene expression through RT-PCR method was carried out using the four Egyptian maize lines K1, K7, G342 and Rg59, which cDNA of the three gene markers and SYBR green reagent were used as working model (Figure 5). The primers of each gene that were mentioned in Table (1) were designed according to the sequences from the GenBank, NCBI, USA. All experiments were repeated three replicates to confirm the results.

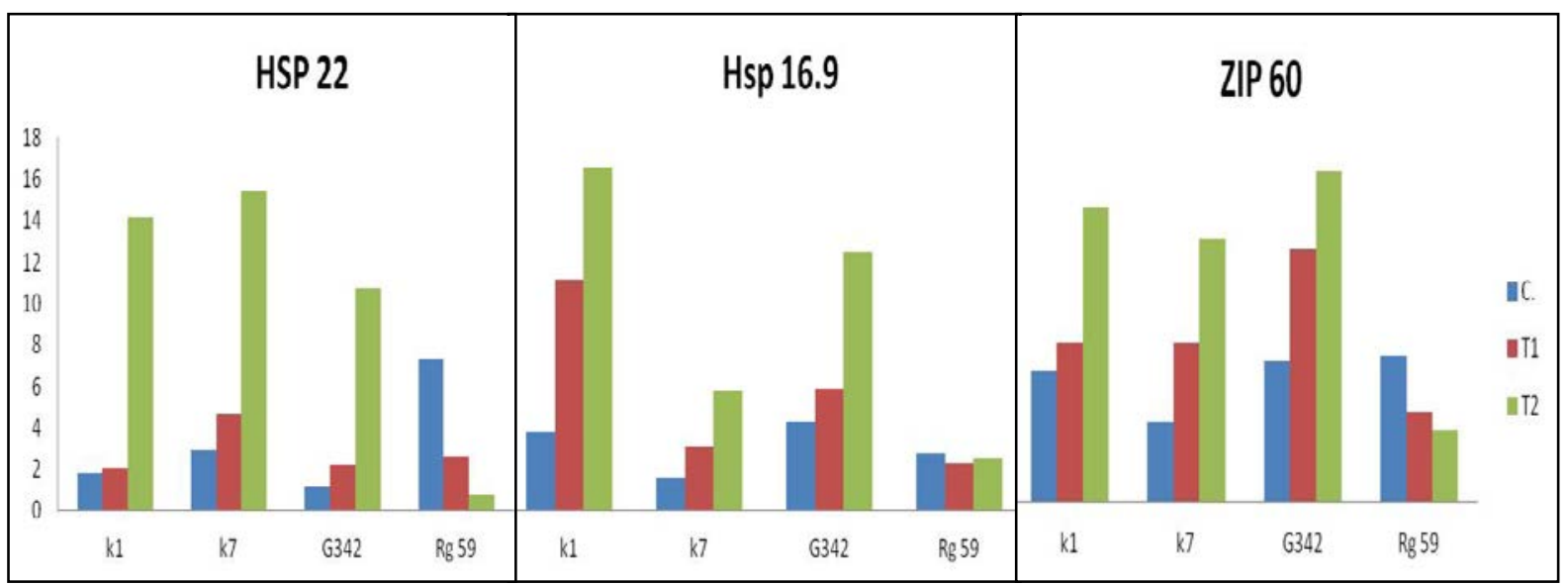

Figure 5. Expression analysis of the three gene markers ZmHSP22, ZmHSP16.9 and ZIP60 in response to HS treatments in the four maize lines. C: control at $25^{\circ} \mathrm{C}$, T1: treatment for $2 \mathrm{~h}$ at $45^{\circ} \mathrm{C}$ and T2: treatment for $4 \mathrm{~h}$ at $45^{\circ} \mathrm{C}$. The vertical axis represents relative transcript level and the horizontal axis represents the maize lines.

Upregulation of the transcription factor ZIP60 at $45^{\circ} \mathrm{C}$ after $4 \mathrm{~h}$ in the line $\mathrm{K} 1$ was almost twice than the control $\left(25^{\circ} \mathrm{C}\right)$ and $\mathrm{HS}$ treatment at $45^{\circ} \mathrm{C}$ after 2 h. HSP 16.9 showed expression level three and four times more than the control after exposing to $45^{\circ} \mathrm{C}$ for $2 \mathrm{~h}$ and $4 \mathrm{~h}$, respectively. Meanwhile, HSP22 gave gene expression about seven-fold after exposing to $45^{\circ} \mathrm{C}$ for $4 \mathrm{~h}$ more than the control. The transcription factor ZIP60 expressed in the inbred line $\mathrm{K} 7$ two times after exposing to $\mathrm{HS}$ at $45^{\circ} \mathrm{C}$ for $2 \mathrm{~h}$ and three times after $4 \mathrm{~h}$ as compared to the control. The two genes HSP16.9 and HSP22 expressed progressively in the line $\mathrm{K} 7$ during time reaching a maximum expression of four and six times respectively after heat exposing to $45^{\circ} \mathrm{C}$ for $4 \mathrm{~h}$ as compared to the control. Regarding the line G342, the transcription factor ZIP60 expressed in control plants and increased progressively with increasing time of exposing to HS treatment. Both of HSP16.9 and HSP22 showed a maximum expression after heat treatment at $45^{\circ} \mathrm{C}$ for $4 \mathrm{~h}$. In contrast, the expression level of the three genes in the line Rg59 appeared in the control more than heat treatments (Figure 5).

\section{Discussion}

The expression levels of the HSP gene markers (ZmHSP70, ZmHSP22, ZmHSP17.9 and ZmHSP17.6) in the four maize lines K1, K7, G342 and Rg59 were evaluated by WB with four antibodies. The results revealed that: 1) The antibodies against HSPs can recognize the corresponding endogenous proteins of the studied maize lines. 2) HSP expression was absent in the untreated plants but induced in the resistant lines K1, K7 and G342 after exposing to HS treatment. However, the majority of the HSP gene markers expressed only in the untreated plants of the line Rg59 which it is consider a heat sensitive line. 3) There are differences in the induction kinetics of HSP gene markers. For example, induction of HSP70 was detected after exposing to $45^{\circ} \mathrm{C}$ for $2 \mathrm{~h}$ whereas induction of HSP17.6 was more evident 
after $4 \mathrm{~h}$ of HT. Induction of HSP17.6 was more intensity in the line $\mathrm{K} 1$ than the other lines after exposing to HT. The gene expression of HSP22 and HSP70 was more intensity in the line G342 than the other lines after exposing to HS treatment, while the same result was shown for HSP70 in the line K7 comparing to the other lines. Higher expression of the four HSP genes that appeared by WB analysis in the heat tolerant lines indicated that they could play a crucial role in conferring heat tolerance. Other researchers revealed similar results such as Verhagen and Kompoliti (2010) who found that WB is a sensitive immunological method for determination of molecular weights of protein antigens and detection of antigens in crude mixtures of proteins. De Vries (2012) reported that linear epitopes can be detected using polyclonal antibodies.

Expression of the three gene markers ZmHSP22, ZmHSP16.9 and ZIP60 in response to HT by RT-PCR analysis were clearly induced in the three lines K1, K7 and G342 which are considered tolerant lines. The expression levels of the three genes in the line Rg59 after exposing to HT were less than those of the control indicating sensitivity against HT. The results of gene expression using RT-PCR correlated with those of WB analysis in response of the three resistant maize lines to HT, which emphasized that the induced expression of the genes in this study protects the plants from the deleterious effects of high temperature stress. Therefore, identification of specific gene(s) playing essential role in HS tolerance could be useful for developing stress resistant genotypes.

Our results are coincided with those reported by other researchers. The rate of HSP synthesis in plants has been shown to be directly proportional to the temperature applied during the stress (Chen et al., 1990). Our experiments showed that the accumulation of HSPs in leaves tissues was also proportional to temperature by two to seven-fold at $45^{\circ} \mathrm{C}$ more than at $25^{\circ} \mathrm{C}$. Andersen et al. (2004) reported that qRT-PCR provides a useful and rapid means of understanding gene expression in living organisms by measuring the expression of target genes across different samples. Zhao et al. (2017) demonstrated that ZmHsf04 is expressed in multiple tissues of maize and was up-regulated significantly after exposing to $42^{\circ} \mathrm{C} \mathrm{HS}$, which the highest value reached 340 times of the control.

Kumar et al. (2019) found five maize specific HSP genes; ZmHsp26, ZmHsp60, ZmHsp70, ZmHsp82 and ZmHsp101 exhibited distinctive expression pattern in response to HS, especially ZmHsp70 showed higher upregulation throughout the stress exposure in a heat tolerant line as compared to a susceptible line. The role of sHSPs in response to environmental stresses has been clearly established by several studies. HSPs have been implicated in functions related to protein assembly or the alteration/maintenance of specific protein conformations (Lindquist and Craig, 1988). ZmHSP16.9 gene enhances both thermotolerance and oxidative stress resistance through the protection of antioxidative enzymes under heat stress condition (Sun et al., 2012). Overexpression of HSP26 in transgenic Arabidopsis enhanced thermotolerance due to increased amount of free proline caused by the elevated proline biosynthetic pathway genes (Xue et al., 2010).

\section{Conclusions}

The expression analysis of HSP genes was carried out by WB and RT-PCR in the four maize inbred lines K1, K7 and G342 (heat tolerant) and Rg59 (heat susceptible) subjected to high temperature stress at seedling stage. The HSP genes exhibited distinctive expression pattern as response to HS. Higher upregulation of ZmHSP70, ZmHSP22, ZmHSP17.9 and ZmHSP17.6 were found throughout the stress exposure to $45^{\circ} \mathrm{C}$ for 2 and $4 \mathrm{~h}$ in the heat tolerant lines as compared to the control $\left(25^{\circ} \mathrm{C}\right)$ and susceptible line. Upregulation of these genes indicated their possible role in protecting plants from the adverse effects of HS. The results indicated that WB and RT-PCR are evident and accurate to detect the gene expression in plants for HSPs induction under abiotic stresses, especially heat stress in maize.

\section{Acknowledgement}

The authors thank the Spanish Agency for International Development Cooperation of Spain for funding this work through the research project "11-CAP-2-1151" and for laboratory assistance.

\section{References}

Andersen CL, Jensen JL and Orntoft TF. 2004. Normalization of real-time quantitative reverse transcription-PCR data: a modelbased variance estimation approach to identify genes suited for normalization, applied to bladder and colon cancer data sets. Cancer Res, 64: 5245-5250.

Bass JJ, Wilkinson DJ, Rankin D, Phillips BE, Szewczyk NJ, Smith K and Atherton PJ. 2017. An overview of technical considerations for western blotting applications to physiological research. Scandinavian J of Med \& Sci in Sports, 27: 4-25.

Berg RJ, Vaessen N, Endtz HP, Schulin T, Vorm ER and Kuijper EJ. 2007. Evaluation of real time PCR and conventional diagnostic methods for the detection of Clostridium edificial associated diarrhea in a prospective multicenter study. J Med Microbiol, 56: 36-42.

Burnette WN. 1981. "Western Blotting”: electrophoretic transfer of proteins from sodium dodecyl sulfate-polyacrylamide gels to unmodified nitrocellulose and radiographic detection with antibody and radio-iodinated protein A. Anal Biochem, 112: 195203.

Chen 0, Lauzon LM, DeRocher AE and Vierling E. 1990. Accumulation, stability, and localization of a major chloroplast heat-shock protein. J Cell Biol, 110: 1873-1883.

Cui F, Liu L, Zhao Q, Zhang Z, Li Q, Lin B, Wu Y, Tang S and Xie Q. 2012. Arabidopsis ubiquitin conjugate UBC32 is an ERAD component that functions in brassinosteroid-mediated salt stress tolerance. Plant Cell, 24: 233-244.

DeVries E. 2012. Patient-centered screening for primary immunodeficiency, a multi-stage diagnostic protocol designed for non-immunologists. Clinical \& Experimental Immunol, 167: 108119.

Hendrick JP and Hartl FU. 1993. Molecular chaperone functions of heat-shock proteins. Annu Rev Biochem, 62: 349-384.

Kumar K, Singh I, Aggarwal C, Tewari I, Kumar A, Yadava P and Rakshit S. 2019. Expression profiling of heat shock protein genes in two contrasting maize inbred lines. Int J Curr Microbiol App Sci, 8: 347-358. 
Lenne C and Douce R. 1994. A low molecular mass heat-shock protein is localized to higher plant mitochondria. Plant Physiol, 105: $1255-1261$.

Lenne C, Block MA, Garin J and Douce R. 1995. Sequence and expression of the mRNA encoding HSP22, the mitochondrial small heat-shock protein in pea leaves. Biochem J, 311: 805-813.

Li D, Wang L, Liu X, Cui D, Chen T, Zhang H and Zhao L. 2011. Deep sequencing of maize small RNAs reveals a diverse set of micro-RNA in dry and imbibed seeds. PloS One, 8: e55107.

Li HC, Zhang HN, Li GL, Liu ZH, Zhang YM, Zhang HM and Guo XL. 2015. Expression of maize heat shock transcription factor gene ZmHsf06 enhances the thermotolerance and droughtstress tolerance of transgenic Arabidopsis. Functional Plant Biol, 42: $1080-1091$

Lilly ST, Drummond RSM, Pearson MN and MacDiarmid RM. 2011. Identification and validation of reference genes for normalization of transcripts from virus-infected Arabidopsis thaliana. Mol Plant Microbe Interact, 24: 294-304.

Lin Y, Zhang C, Lan H, Gao S, Liu H, Liu J, Cao M, Pan G, Rong $\mathrm{T}$ and Zhang S. 2014. Validation of potential reference genes for qPCR in maize across abiotic stresses, hormone treatments, and tissue types. PLoS One, 9: e95445.

Lindquist S and Craig E. 1988. The heat shock proteins. Annu Rev Genet, 22: 631-677.

Lund AA, Blum PH, Bhattramakki D and Elthon TE. 1998. Heatstress response of maize mitochondria. Plant Physiol, 116: 10971110.

Mahmoud FE, Rashed MA, Khalil KM and Abou-Deif MH. 2018 Identification and characterization of heat shock proteins in four Egyptian maize inbred lines (Zea mays L.). Arab Universities J of Agric Sci, 26: 1203-1211.

Okegawa Y, Koshino M, Okushima T and Motohashi K. 2016. Application of preparative disk gel electrophoresis for antigen purification from inclusion bodies. Protein Expression and Purification, 118: 77-82.
Sachs MM and Ho THD. 1986. Alteration of gene expression during environmental stress in plants. Annu Rev Plant Physiol, 37: 363-376.

Schröder H, Langer T, Hartl FU and Bukau B. 1993. DnaK, DnaJ and GrpE form a cellular chaperone machinery capable of repairing heat-induced protein damage. EMBO J, 12: 4137-4144.

Song J, Weng Q, Ma H, Yuan J, Wang L and Liu_Y. 2016. Cloning and expression analysis of the Hsp70 gene ZmERD2 in Zea mays. Biotechnol \& Biotechnological Equipment, 30: 219226.

Sun L, Liu Y, Kong X, Zhang D, Pan J, Zhou Y et al. 2012. ZmHSP16.9, a cytosolic class I small heat shock protein in maize (Zea mays), confers heat tolerance in transgenic tobacco. Plant Cell Rep, 31:1473-1484.

Towbin H, Staehelin T and Gordon J. 1979. Electrophoretic transfer of proteins from polyacrylamide gels to nitrocellulose sheets: procedure and some applications. Proc Natl Acad Sci, 76: 4350-4354.

Verhagen L and Kompoliti K. 2010. Encyclopedia of Movement Disorders. Academic Press. https://www.worldcat.org/title/encyclopedia-of-movementdisorders/oclc/614267004

Wong ML and Medrano JF. 2005. Real-time PCR for mRNA quantitation. BioTechniques, 39: 75-85.

Xue Y, Xiong A, Li X, Zha D and Yao Q. 2010. Over-expression of heat shock protein gene hsp26 in Arabidopsis thaliana enhances heat tolerance. Biol Plantarum, 54:105-111.

Zhang X, Rerksiri W, Liu A, Zhou X, Xiong H, Xiang J, Chen X and Xiong X. 2013. Transcriptome profile reveals heat response mechanism at molecular and metabolic levels in rice flag leaf. Gene, 530: 185-192.

Zhao L, Zhang H, Duan S, Guo X and Li G. 2017. Cloning and characterization of maize (Zea mays) $\mathrm{ZmHsf04}$ gene and its regulating role in thermotolerance. $\mathrm{J}$ of Agric Biotechnol, 25: 1411-1422. 